\title{
ANALISIS END-USER COMPUTING SATISFACTION (EUCS) PADA APLIKASI MOBILE UNIVERSITAS BINA DARMA
}

\author{
${ }^{1}$ Muhammad Aja Sugandi, ${ }^{2}$ R.M. Nasrul Halim* \\ ${ }^{1}$ Sistem Informasi, Fakultas Ilmu Komputer, Universitas Bina Darma \\ ${ }^{2}$ Teknik Informatika, Fakultas Ilmu Komputer, Universitas Bina Darma \\ Jl. Jend. A. Yani No. 3 Palembang 30264 \\ Email: majasugandi18@gmail.com,nasrul.halim@binadarma.ac.id \\ *Corresponding Author: nasrul.halim@binadarma.ac.id
}

(Diterima: 11 Oktober 2019, direvisi: 11 Desember 2019, disetujui: 21 Desember 2019)

\begin{abstract}
Nowadays, the mobile phones are growing very fast and becoming one of alternative media which can be used for delivering information needed by everyone without any time or place restrictions so the information can be quickly accessed anytime and anywhere. Currently, Bina Darma University has a mobile-based academic information system for students. The students' UBD mobile application is an Android-based application created to facilitate them doing college activities such as checking study results, study plan, payment history, assessment information and others. Satisfaction is one of the ways in measuring this application. Therefore, this research was aimed to measure the satisfaction of Bina Darma University students on the use of android-based students' UBD mobile application by using the EUCS (End-User Computing Satisfaction) method. The research method used in this study was a descriptive analysis method with a quantitative approach or statistical. The results of this study showed that from 100 respondents, 70 respondents were satisfied with the students' UBD mobile application.
\end{abstract}

\section{Keywords: Application, EUCS, UBD Mobile}

\begin{abstract}
ABSTRAK
Mobile phone yang saat ini telah berkembang sangat cepat menjadi salah satu alternatif media yang dapat digunakan untuk penyampaian informasi yang dibutuhkan oleh semua orang tanpa ada batasan waktu maupun tempat sehingga informasi dengan cepat dapat diakses kapan saja dan dimana saja. Universitas Bina Darma saat ini sudah memiliki sistem informasi akademik berbasis mobile untuk mahasiswa. Aplikasi UBD mobile mahasiswa adalah sebuah aplikasi berbasis android yang dibuat untuk memudahkan mahasiswa untuk memudahkan kegiatan-kegiatan kuliah seperti melihat kartu hasil studi, kartu rencana studi, riwayat pembayaran, informasi nilai dan sebagainya. Salah satu hal yang menjadi alat ukur dalam keberhasilan sebuah aplikasi mobile adalah kepuasaan pengguna akhir dari aplikasi tersebut. Penelitian ini bertujuan untuk mengukur kepuasan mahasiswa Universitas Bina Darma terhadap penggunaan aplikasi UBD mobile untuk mahasiswa berbasis android menggunakan metode EUCS (End-User Computing Satifaction). Metode penelitian yang digunakan dalam penelitian ini adalah metode analisis deskriptif dengan pendekatan kuantitatif atau statistik. Hasil penelitian ini adalah dari 100 responden, 70 responden merasa puas dengan Aplikasi UBD mobile mahasiswa.
\end{abstract}

Kata Kunci: Aplikasi, EUCS, UBD Mobile

\section{PENDAHULUAN}

Penggunaan teknologi mobile phone yang saat ini telah berkembang sangat cepat menjadi salah satu alternatif media penyampaian informasi disegala bidang termasuk dibidang akademik. Akses informasi yang cepat dan terkini adalah salah satu andalan instansi akademik untuk menyampaikan informasi yang kepada mahasiswa. Penggunaan teknologi mobile phone atau yang sering disebut aplikasi mobile dapat digunakan untuk penyampaian informasi yang dibutuhkan oleh mahasiswa tanpa ada batasan waktu maupun tempat. Disamping itu, aplikasi mobile juga memungkinkan penggunanya 
untuk mendapatkan update data informasi yang disampaikan oleh instansi akademik sehingga informasi dengan cepat dapat diakses kapan saja dan dimana saja.

Universitas Bina Darma (UBD) saat ini sudah memiliki aplikasi berbasis mobile android untuk mahasiswa. Android adalah "suatu sistem operasi yang berbasis pada perangkat mobile. Android manganut sistem open source yang memudahkan bagi setiap pengembang yang ingin mengembangkan atau membuat suatu aplikasi pada ponsel dengan platform android" [1]. Android merupakan "salah satu sistem operasi yang dipergunakan pada telepon seluler dan komputer tablet layar sentuh (touch screen) dengan berbasis Linux. Basis sistem operasi android adalah kernel linux yang merupakan open source sehingga sistem operasi android memungkinkan pengembang untuk selalu menciptakan aplikasi android sendiri yang bisa digunakan untuk berbagai macam alat yang bergerak (mobile)" [2].

Aplikasi mobile adalah "perangkat lunak yang berjalan pada perangkat mobile seperti smartphone atau tablet PC. Aplikasi mobile juga dikenal sebagai aplikasi yang dapat diunduh dan memiliki fungsi tertentu sehingga menambah fungsionalitas dari perangkat mobile itu sendiri. Untuk mendapatkan aplikasi mobile yang diinginkan, user dapat mengunduhnya melalui situs tertentu sesuai dengan sistem operasi yang dimiliki. Google Play dan iTunes merupakan beberapa contoh dari situs yang menyediakan beragam aplikasi bagi pengguna Android dan iOS untuk mengunduh aplikasi yang diinginkan" [3]. Aplikasi mobile "adalah sebuah aplikasi yang memungkinkan Anda melakukan mobilitas dengan menggunakan perlengkapan seperti PDA, telepon seluler atau Handphone" [4].

"Untuk menunjang kinerja suatu institusi atau organisasi sebuah teknologi informasi sangatlah dibutuhkan, dengan adanya teknologi informasi tingkat efisiensi dan efektivitas dari sebuah proses akan meningkat, salah satunya adalah dengan munculnya aplikasi mobile yang dapat memudahkan pengguna melakukan suatu transaksi maupun memperoleh informasi" [5].

Aplikasi UBD mobile mahasiswa adalah sebuah aplikasi berbasis android yang dibuat untuk memudahkan mahasiswa UBD untuk memudahkan kegiatan-kegiatan kuliah seperti melihat kartu hasil studi, kartu rencana studi, riwayat pembayaran, informasi nilai dan sebagainya melalui suatu aplikasi di mobile phone. Dengan adanya aplikasi mobile ini memudahkan mahasiswa-mahasiswi dapat melihat informasi tentang akademik melalui aplikasi di android tanpa harus dibatasi oleh ruang dan waktu. Berdasarkan sumber dari google playstore, pengguna aktif UBD mobile sampai dengan bulan Januari 2019 telah diunduh oleh 2774 penginstal. Hal tersebut dapat menjadikan aplikasi UBD mobile sebagai aplikasi yang berguna bagi penggunanya dalam hal ini adalah mahasiswa. Salah satu hal yang menjadi alat ukur dalam keberhasilan sebuah aplikasi mobile adalah kepuasaan pengguna akhir dari aplikasi mobile tersebut. "Kesuksesan sistem informasi dipengaruhi oleh 6 (enam) faktor yaitu: Kualitas Sistem, Kualitas Informasi, Kualitas Layanan, Penggunaan Sistem, Kepuasan Pengguna, dan Manfaat Sistem" [6]. "Kinerja sistem informasi dapat dilihat dari kepuasan pengguna dalam penggunaan sistem informasi tersebut" [7]. "Dengan memperhatikan aspek kepuasan pengguna dapat meningkatkan kualitas sistem serta kualitas layanan menjadi lebih optimal" [8].

Sistem yang berkualitas "adalah sistem yang tepat guna, memenuhi standar yang telah ditetapkan dan senantisa mengikuti perkembangan jaman serta kemajuan teknologi. Untuk menghindari adanya penolakan terhadap sistem yang dikembangkan maka kualitas sistem harus baik, dan ini akan berpengaruh pada tingkat kepuasan pengguna dari sistem tersebut" [9]. "Kualitas sistem memerlukan indikator untuk dapat mengukur seberapa baik kualitas dari suatu sistem. Suatu sistem dapat dikatakan berkualitas jika sistem dirancang untuk memenuhi kepuasan pengguna melalui kemudahan, kecepatan akses, keandalan sistem, fleksibilitas dan keamanan sistem" [10]. Salah satu metode yang dapat digunakan untuk mengukur tingkat kepuasan pengguna aplikasi mobile adalah metode End User Computing Satisfaction (EUCS).

EUCS merupakan alat untuk mengukur tingkat kepuasan pengguna suatu sistem atau aplikasi dan hasilnya akan dianalisis menggunakan metode statistik. Variabel EUCS terdiri dari lima variabel, yaitu: isi, keakuratan, bentuk, kemudahan dan ketepatan waktu. Hasil analisisnya merupakan pernyataanpernyataan yang menjelaskan kelebihan dan kekurangan atau baik dan buruknya nilai penggunaan aplikasi dalam penelitian ini adalah aplikasi UBD mobile mahasiswa. End User Computing Satisfaction (EUCS) "adalah cara untuk mengukur tingkat kepuasan dari pengguna suatu sistem aplikasi dengan membandingkan antara harapan dan kenyataan dari sebuah sistem informasi. Definisi End User Computing Satisfaction dari sebuah sistem informasi adalah evaluasi secara keseluruhan dari para 
pengguna sistem informasi yang berdasarkan pengalaman mereka dalam menggunakan sistem tersebut" [11].

Penelitian ini bertujuan untuk mengukur kepuasan mahasiswa Universitas Bina Darma terhadap penggunaan aplikasi UBD mobile mahasiswa dengan menerapkan metode EUCS (End-User Computing Satifaction) sehingga dapat menjadi acuan dalam pengembangan aplikasi UBD mobile mahasiswa menjadi lebih baik.

\section{TINJAUAN PUSTAKA}

Model evaluasi EUCS dikembangkan oleh Doll \& Torkzadeh. "Evaluasi dengan menggunakan model ini lebih menekankan kepuasan (satisfaction) pengguna akhir terhadap aspek teknologi, dengan menilai isi, keakuratan, format, waktu dan kemudahan penggunaan dari sistem" [11]. EUCS "adalah alat untuk mengevaluasi kepuasan pengguna sistem secara keseluruhan yang didasari dengan pengalaman mereka dari sisi afektif dalam menggunakan sistem sehingga hasil evaluasi dapat digunakan sebagai bahan pertimbangan dalam pengembangan sistem berikutnya. Instrumen EUCS terdiri dari 12 item yang terbagi ke dalam 5 komponen untuk mengukur kualitas sistem dan informasi. 5 komponen tersebut meliputi content (isi), accuracy (akurasi), format (bentuk), ease of use (kemudahan penggunaan), dan timeliness (ketepatan waktu)" [8].

Beberapa penelitian tentang EUCS antara lain penelitian yang dilakukan oleh Sarja dengan judul "Pengukuran Kepuasan Pengguna Sistem Informasi Dosen Menggunakan Metode EUCS". Penelitian ini mengukur tingkat kepuasan pengguna Sistem Informasi Dosen di STIKOM Bali menggunakan EUCS dengan 100 orang responden serta dianalisis menggunakan statistik. Hasil yang yang didapatkan bahwa "berdasarkan hasil evaluasi, nilai hasil evaluasi isi adalah 3.8425 , akurasi adalah 3.825, bentuk adalah 3.703, kemudahan pemakaian adalah 3.600 dan ketepatan waktu adalah 3.709. Sesuai dengan hasil evaluasi, didapatkan bahwa nilai evaluasi kelima indikator $>3$. Hal ini menunjukkan secara keseluruhan, dosen cukup puas dengan aplikasi SID yang ada di STIKOM Bali” [12].

Peneltian selanjutnya adalah penelitian yang dilakukan oleh Dalimunthe dan Ismiati dengan judul "Analisis Tingkat Kepuasan Pengguna Online Public Access Catalog (OPAC) dengan Metode EUCS (Studi Kasus: Perpustakaan UIN SUSKA Riau)". Penelitian ini membahas tentang tingkat kepuasan pengguna terhadap penggunaan OPAC menggunakan metode EUCS di perpustakaan UIN SUSKA Riau dengan 100 orang responden dan dianalisis menggunakan statistik. Hasil yang didapatkan adalah "pengguna merasa puas dengan layanan OPAC. Hal ini ditunjukkan berdasarkan persentase sebesar $74,10 \%$ pengguna setuju dengan adanya OPAC" [11].

Berdasarkan penelitian yang dilakukan oleh Sarja dan Dalimunthe dapat disimpulkan bahwa faktor yang mempengaruhi kepuasan pengguna terhadap sistem dapat diukur menggunakan lima variabel EUCS yaitu berdasarkan isi, akurasi, bentuk, kemudahan pemakaian dan ketepatan waktu. Penelitian tersebut sama-sama mengukur tingkat kepuasan pengguna menggunakan EUCS dan dianalisis dengan statistik.

\section{METODE PENELITIAN}

Jenis penelitian ini menggunakan metode analisis deskriptif dengan pendekatan kuantitatif atau statistik, berupa hasil penelitian yang diolah dan dianalisis untuk diambil kesimpulannya. "Penelitian kuantitatif bertujuan untuk menggambarkan dan meringkas dari berbagai situasi dan kondisi yang muncul dimasyarakat yang menjadi objek penelitian, untuk melakukan penilaian berdasarkan persepsi responden" [13].

Objek penelitian ini adalah aplikasi UBD Mobile Mahasiswa. Jenis data yang dipakai dalam peneltian ini berupa data-data primer dan data-data sekunder. Data primer yang diperoleh berupa data hasil kuisioner dan wawancara, sedangkan data sekunder berupa literatur atau jurnal-jurnal sebagai panduan dalam melaksanakan penelitian.

\subsection{Pengumpulan Data}

Teknik pengumpulan data dengan cara melakukan wawancara kepada pembuat aplikasi UBD mobile dan kepada mahasiswa UBD serta menyebarkan kuisioner atau angket dengan menyebarkannya kepada seluruh mahasiswa di Universitas Bina Darma dengan mengunakan metode random sampling. 
Populasi dalam penelitian ini adalah pengguna akhir aplikasi UBD mobile mahasiswa di Universitas Bina Darma. Populasi penelitian yang ditetapkan adalah mahasiswa yang telah menginstal aplikasi UBD mobile android sebanyak 2774 sampai dengan bulan januari 2019 yang bersumber dari google playstore. Penelitian ini menggunakan teknik pengambilan sampel (sampling) karena peneliti tidak mampu menjangkau keseluruhan populasi dengan pendekatan non-probability sampling melalui metode convenience sampling, yaitu saat responden yang dijadikan sampel sedang berada di lokasi penelitian serta dapat diwawancarai. Di awal kuisioner terdapat screening, dimana mahasiswa yang dijadikan responden adalah mahasiswa yang sudah pernah menggunakan aplikasi UBD mobile sebelumnya minimal satu kali. Jumlah sampel yang diambil menggunakan rumus slovin sehingga dari 2774 populasi didapatkan 100 orang responden dengan taraf kesalahan $10 \%$.

$$
n=\frac{N}{N \cdot d^{2}+1}
$$

$$
\begin{aligned}
& \text { Keterangan: } \\
& \mathrm{n}=\text { ukuran sampel } \\
& \mathrm{N}=\text { ukuran populasi } \\
& \mathrm{d}=\text { persen kelonggaran ketidaktelitian karena kesalahan } \\
& n=\frac{2774}{2774.0,1 \times 0,1+1} \\
& n=\frac{2774}{2774.0,01+1} \\
& n=\frac{2774}{28,74} \\
& \mathrm{n}=96,52052888=100 \text { responden }
\end{aligned}
$$

Responden dalam penelitian ini adalah mahasiswa sebagai pengguna aktif aplikasi UBD Mobile Mahasiswa di lingkungan kampus Bina Darma Palembang, dengan jumlah sampel sebesar 100 Responden. Karakteristik responden diukur berdasarkan program studi, semester dan jenis kelamin. Data hasil penyebaran kuisioner berdasarkan jenis kelamin dari dapat dilihat pada Tabel 1 dan untuk lebih jelasnya dapat dilihat pada Gambar 1.

Tabel 1 Karakteristif Responden Berdasarkan Jenis Kelamin

\begin{tabular}{llrrr}
\hline & Frequency & Percent & Valid Percent & Cumulative Percent \\
\hline Valid laki-laki & 48 & 48.0 & 48.0 & 48.0 \\
Perempuan & 52 & 52.0 & 52.0 & 100.0 \\
Total & 100 & 100.0 & 100.0 & \\
\hline
\end{tabular}

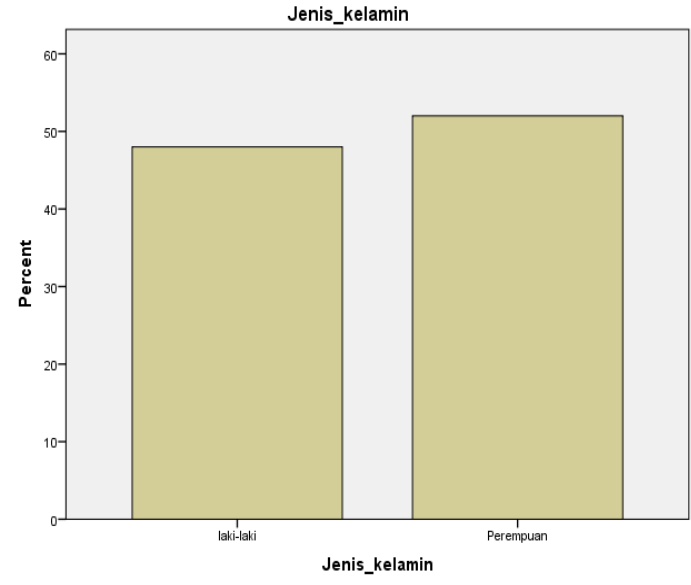

Gambar 1 Grafik responden berdasarkan jenis kelamin 
Data karakkteristik responden berdasarkan program studi dapat dilihat pada tabel 2 dan untuk lebih jelasnya dapat dilihat pada Gambar 2.

Tabel 2 Karakteristif Responden Berdasarkan Program Studi

\begin{tabular}{|c|c|c|c|c|c|}
\hline & & Frequency & Percent & $\begin{array}{c}\text { Valid } \\
\text { Percent } \\
\end{array}$ & $\begin{array}{c}\text { Cumulative } \\
\text { Percent }\end{array}$ \\
\hline \multirow[t]{13}{*}{ Valid } & Sastra Inggris & 6 & 6.0 & 6.0 & 6.0 \\
\hline & Akuntansi & 19 & 19.0 & 19.0 & 25.0 \\
\hline & Manajemen & 9 & 9.0 & 9.0 & 34.0 \\
\hline & Pendidikan B.Indonesia & 3 & 3.0 & 3.0 & 37.0 \\
\hline & Pendidikan Olahraga & 3 & 3.0 & 3.0 & 40.0 \\
\hline & Sistem Informasi & 27 & 27.0 & 27.0 & 67.0 \\
\hline & Teknik Informatika & 15 & 15.0 & 15.0 & 82.0 \\
\hline & Ilmu Komunikasi & 1 & 1.0 & 1.0 & 83.0 \\
\hline & Psikologi & 6 & 6.0 & 6.0 & 89.0 \\
\hline & Teknik Elektro & 5 & 5.0 & 5.0 & 94.0 \\
\hline & Teknik Industri & 4 & 4.0 & 4.0 & 98.0 \\
\hline & Teknik Sipil & 2 & 2.0 & 2.0 & 100.0 \\
\hline & Total & 100 & 100.0 & 100.0 & \\
\hline
\end{tabular}

Fakultas

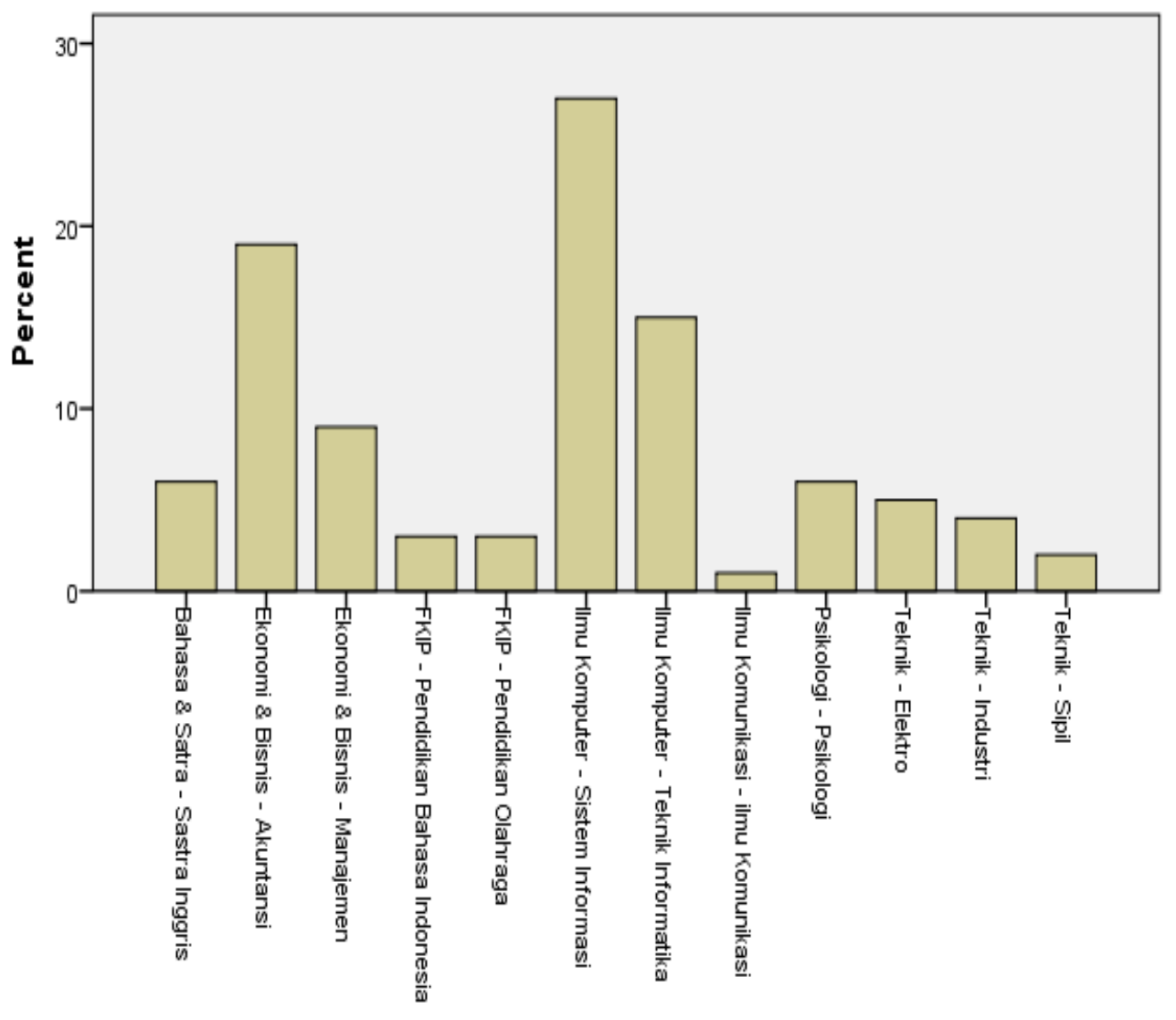

Fakultas

\section{Gambar 2 Grafik responden berdasarkan program studi}

Data karakkteristik responden berdasarkan semester dapat dilihat pada Tabel 3 dan untuk lebih jelasnya dapat dilihat pada Gambar 3. 
Tabel 3 Karakteristif Responden Berdasarkan Semester

\begin{tabular}{llrrrr}
\hline & Frequency & Percent & Valid Percent & Cumulative Percent \\
\hline Valid & 10 & 2 & 2.0 & 2.0 & 2.0 \\
& 2 & 16 & 16.0 & 16.0 & 18.0 \\
& 23 & 23.0 & 23.0 & 41.0 \\
& 33 & 33.0 & 33.0 & 74.0 \\
6 & 26 & 26.0 & 26.0 & 100.0 \\
8 & 100 & 100.0 & 100.0 & \\
\hline
\end{tabular}

Data yang diperlukan dalam penelitian ini meliputi data mengenai Content $\left(\mathrm{X}_{1}\right)$, Accuracy $\left(\mathrm{X}_{2}\right)$, Format $\left(\mathrm{X}_{3}\right)$, Ease of Use $\left(\mathrm{X}_{4}\right)$, Timelines $\left(\mathrm{X}_{5}\right)$, dan Satisfaction $(\mathrm{Y})$. Setiap variabel penelitian didefinisikan dan diukur skalanya. Skala yang digunakan dalam penelitian ini adalah skala likert. Penelitian ini melihat pengaruh variabel X1, X2, X3, X4 dan X5 secara parsial terhadap variabel Y, serta pengaruh X1, X2, X3, X4, X5 secara bersama-sama terhadap Y.

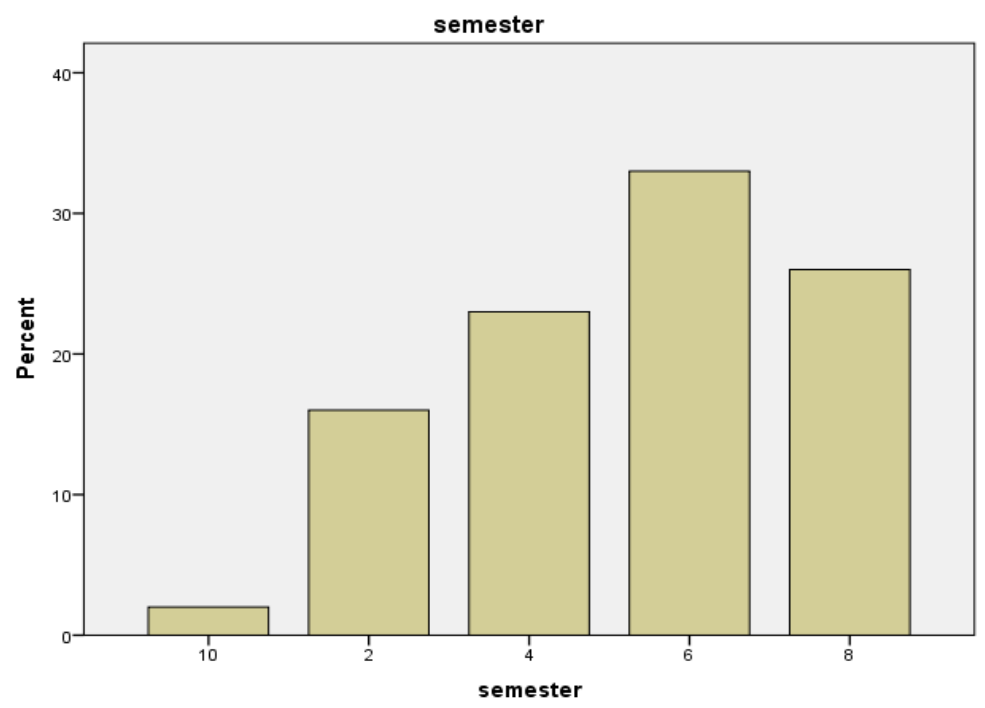

Gambar 3 Grafik responden berdasarkan semester

Skala likert "digunakan untuk mengukur sikap atau pendapat seseorang atau sejumlah kelompok terhadap sebuah fenomena sosial yang dimana jawaban setiap item instrumen mempunyai gradasi dari sangat positif sampai sangat negatif. Dengan skala likert yang diukur dijabarkan menjadi indikator variabel" [14], seperti ditunjukkan pada Tabel 4.

Tabel 4 Skala Linkert [15]

\begin{tabular}{cl}
\hline Angka & \multicolumn{1}{c}{ Keterangan } \\
\hline 1 & Sangat Tidak Puas \\
2 & Tidak Puas \\
3 & Cukup Puas \\
4 & Puas \\
5 & Sangat Puas \\
\hline
\end{tabular}

\subsection{Analisis Data}

Teknik analisis data yang digunakan yaitu: 1) Uji Validitas (Test of validity), "pengujian Validitas perlu dilakukan Sebelum instrumen penelitian digunakan untuk mengumpulkan data. Hal ini dapat digunakan untuk mendapatkan data yang valid dari instrumen yang valid" [15]. Uji validitas dalam penelitian ini dengan bantuan program Komputer SPSS dengan 23 item atau pertanyaan. 2) Uji 
Reliabilitas (Test of realibility), bertujuan untuk mengukur konsistennya jawaban responden terhadap item-item pertanyaan yang terdapat di kuesioner. 3) Uji $\mathrm{R}^{2}$, dilakukan Untuk mendapatkan seberapa besa variabel independen ke dependen. guna menggukur seberapa jauh menerangkan variasi variabel independen. 4) Uji T, untuk melihat koefisien regresi masing-masing variabel bebas (X) yang dipakai secara terpisah berpengaruh atau tidak terhadap variabel terikat (Y). 5) Uji F, untuk menguji apakah variabel independen secara bersamaan berpengaruh terhadapa dependen kepuasaan dengan membandingkan $\mathrm{f}$ hitung dengan $\mathrm{f}$ tabel.

\section{HASIL DAN PEMBAHASAN}

Hasil yang akan didapat dalam penelitian ini adalah kepuasaan pengguna aplikasi UBD Mobile Mahasiswa menggunakan metode End User Satisfaction (EUCS). Penelitian ini membahas mengenai pengaruh dari ke lima Variabel EUCS yaitu Isi (content), Akurasi (accuracy), Bentuk (Format), Kemudahan (Ease of use) dan Ketepatan Waktu (timeliness) terhadap kepuasan Pengguna (User Satisfaction).

\subsection{Hasil Pengumpulan Data}

Berdasarkan hasil penyebaran kuisioner didapatkan data jawaban responden terhadap aplikasi UBD mobile mahasiswa melalui variabel isi, akurasi, format, kemudahaan dan ketepatan waktu. Data hasil jawaban responden terhadap variabel isi (content) dapat dilihat pada Tabel 5.

Tabel 5 Jawaban Responden terhadap variabel isi (content)

\begin{tabular}{l|l|l|l|l|l}
\hline \multicolumn{7}{|c}{ Variable content (X1) } \\
\hline Jawaban & C1 & C2 & C3 & Total & $\%$ \\
\hline Sangat tidak puas & 1 & 1 & 2 & 4 & 1.3 \\
Tidak puas & 2 & 2 & 15 & 19 & 6.3 \\
Cukup puas & 25 & 27 & 22 & 74 & 24.6 \\
Puas & 52 & 54 & 48 & 154 & 51.3 \\
Sangat puas & 20 & 16 & 13 & 49 & 16.3 \\
\hline Total & 100 & 100 & 100 & 300 & $100 \%$ \\
\hline
\end{tabular}

Berdasarkan data pada Tabel 5, terlihat bahwa pada variabel Isi (content), mayoritas responden menjawab puas terhadap isi yang dihasilkan aplikasi UBD mobile mahasiswa. Selanjutnya data hasil jawaban responden terhadap variabel Akurasi (accuracy), dapat dilihat pada Tabel 6.

Tabel 6 Jawaban Responden terhadap variabel akurasi (accuracy)

\begin{tabular}{l|l|l|l|l|l|l}
\hline \multicolumn{7}{c}{ Variable Accuracy (X2) } \\
\hline Jawaban & A1 & A2 & A3 & A4 & Total & $\%$ \\
\hline Sangat tidak puas & 1 & 0 & 0 & 1 & 2 & 0.52 \\
Tidak puas & 9 & 3 & 5 & 3 & 20 & 5.23 \\
Cukup puas & 19 & 21 & 24 & 20 & 66 & 17.2 \\
Puas & 47 & 59 & 55 & 54 & 215 & 56.2 \\
Sangat puas & 24 & 17 & 16 & 22 & 79 & 20.6 \\
\hline Total & 100 & 100 & 100 & 100 & 382 & $100 \%$ \\
\hline
\end{tabular}

Berdasarkan data pada Tabel 6, terlihat bahwa pada variabel akurasi mayoritas responden menjawab puas terhadap keakuratan yang dihasilkan aplikasi UBD mobile mahasiswa. Selanjutnya data hasil jawaban responden terhadap variabel Bentuk (format), dapat dilihat pada Tabel 7.

Berdasarkan data pada tabel Tabel 7, terlihat bahwa pada variabel bentuk mayoritas responden menjawab puas terhadap bentuk yang dihasilkan aplikasi UBD mobile mahasiswa. Selanjutnya data hasil jawaban responden terhadap variabel Kemudahan (Ease of use), dapat dilihat pada Tabel 8. 
Tabel 7 Jawaban Responden terhadap variabel bentuk (format)

\begin{tabular}{l|l|l|l|l|l}
\hline \multicolumn{7}{|c}{ Variable Format (X3) } \\
\hline Jawaban & F1 & F2 & F3 & Total & $\%$ \\
\hline Sangat tidak puas & 1 & 1 & 0 & 2 & 0.6 \\
Tidak puas & 4 & 5 & 3 & 12 & 4 \\
Cukup puas & 18 & 37 & 22 & 77 & 25.6 \\
Puas & 53 & 39 & 58 & 150 & 50 \\
Sangat puas & 24 & 18 & 17 & 59 & 19.6 \\
\hline Total & 100 & 100 & 100 & 300 & $100 \%$ \\
\hline
\end{tabular}

Tabel 8 Jawaban Responden Terhadap Variabel Kemudahan (Ease Of Use)

\begin{tabular}{l|l|l|l|l|l|l}
\hline \multicolumn{7}{c}{ Variable Ease of use (X4) } \\
\hline Jawaban & E1 & E2 & E3 & E4 & Total & $\%$ \\
\hline Sangat tidak puas & 0 & 0 & 0 & 0 & 0 & 0 \\
Tidak puas & 3 & 2 & 2 & 4 & 11 & 2.75 \\
Cukup puas & 22 & 23 & 28 & 24 & 97 & 24.3 \\
Puas & 52 & 54 & 52 & 60 & 218 & 54.6 \\
Sangat puas & 23 & 20 & 18 & 12 & 73 & 18.2 \\
\hline Total & 100 & 100 & 100 & 100 & 399 & $100 \%$ \\
\hline
\end{tabular}

Berdasarkan data pada Tabel 8, terlihat bahwa pada variabel Kemudahan mayoritas responden menjawab puas terhadap kemudahan yang dihasilkan aplikasi UBD mobile mahasiswa. Selanjutnya data hasil jawaban responden terhadap variabel Ketepatan Waktu (timeliness), dapat dilihat pada Tabel 9.

Tabel 9 Jawaban Responden terhadap variabel ketepatan waktu (timeliness)

\begin{tabular}{l|l|l|l|l|l}
\hline \multicolumn{7}{|c}{ Variable Timliness (X5) } \\
\hline Jawaban & T1 & T2 & T3 & Total & $\%$ \\
\hline Sangat tidak puas & 1 & 0 & 2 & 3 & 1 \\
Tidak puas & 1 & 4 & 9 & 14 & 4.6 \\
Cukup puas & 17 & 23 & 24 & 64 & 21.3 \\
Puas & 43 & 49 & 44 & 136 & 45.3 \\
Sangat puas & 38 & 24 & 21 & 83 & 27.6 \\
\hline Total & 100 & 100 & 100 & 300 & $100 \%$ \\
\hline
\end{tabular}

Berdasarkan data pada Tabel 9, terlihat bahwa pada variabel Ketepataan mayoritas responden menjawab Puas terhadap Ketepataan waktu yang dihasilkan aplikasi UBD mobile mahasiswa. Selanjutnya data hasil jawaban responden terhadap variabel kepuasan (satisfaction), dapat dilihat pada Tabel 10

Tabel 10 Jawaban Responden Terhadap Variabel Kepuasan (Satisfaction)

\begin{tabular}{l|l|l|l|l|l|l|l|l}
\hline \multicolumn{1}{c}{ Variable Satisfaction (Y) } \\
\hline Jawaban tidak & S1 & S2 & S3 & S4 & S5 & S6 & Total & $\%$ \\
\hline Sangat tias & & 0 & 0 & 1 & 1 & 2 & 5 & 0.83 \\
puas & 1 & 2 & 4 & 3 & 2 & 0 & 12 & 2 \\
Tidak puas & 31 & 26 & 27 & 21 & 21 & 20 & 146 & 24.3 \\
Cukup puas & 42 & 51 & 49 & 52 & 52 & 52 & 298 & 49.6 \\
Puas & 25 & 21 & 20 & 23 & 24 & 26 & 139 & 23.1 \\
Sangat puas & 100 & 100 & 100 & 100 & 100 & 100 & 600 & 100 \\
\hline Total & & & & & & &
\end{tabular}

Berdasarkan data pada Tabel 9, terlihat bahwa pada variabel Kepuasaan (Y), mayoritas responden menjawab Puas terhadap Kepuasaan yang dihasilkan aplikasi UBD mobile mahasiswa. 


\subsection{Hasil Analisis Data}

\subsubsection{Hasil Uji Validitas}

Uji validitas diukur dengan cara membandingkan nilai rhitung dan rtabel dengan ketentuan jika rhitung > rtabel, maka item tersebut dinyatakan valid. Dalam penelitian ini didapat r-tabel sebesar 0.195 (2-tailed). Jika Nilai pearson correlation > nilai pebanding berupa r-kritis atau $r$ tabel. Maka item tersebut valid diuji melalui program SPSS, yang dapat dilihat pada Tabel 11.

Tabel 11 Hasil Uji Validitas

\begin{tabular}{lccc}
\hline \multicolumn{1}{c}{ Variabel } & r hitung & r tabel & Keterangan \\
\hline Isi (X1) & & & \\
C1 & .859 & 0.195 & Valid \\
C2 & .820 & 0.195 & Valid \\
C3 & .825 & 0.195 & Valid \\
Akurasi (X2) & & & \\
A1 & .794 & 0.195 & Valid \\
A2 & .789 & 0.195 & Valid \\
A3 & .809 & 0.195 & Valid \\
A4 & .795 & 0.195 & Valid \\
Bentuk(X3) & & & \\
F1 & .823 & 0.195 & Valid \\
F2 & .813 & 0.195 & Valid \\
F3 & .816 & 0.195 & Valid \\
Kemudahan (X4) & & & \\
E1 & .788 & 0.195 & Valid \\
E2 & .719 & 0.195 & Valid \\
E3 & .734 & 0.195 & Valid \\
E4 & .595 & 0.195 & Valid \\
Ketepataan waktu (X5) & & & \\
T1 & .721 & 0.195 & Valid \\
T2 & .844 & 0.195 & Valid \\
T3 & .786 & 0.195 & Valid \\
Kepuasaan (Y) & & & \\
S1 & .819 & 0.195 & Valid \\
S2 & .819 & 0.195 & Valid \\
S3 & .738 & 0.195 & Valid \\
S4 & .853 & 0.195 & Valid \\
S5 & .736 & 0.195 & Valid \\
S6 & .815 & 0.195 & Valid \\
\hline
\end{tabular}

\subsubsection{Hasil Uji Realibilitas}

Uji Realibilitas dilakukan untuk mengetahui konsistensi alat ukur dalam mengukur gejala yang sama. Syarat untuk menyatakan jika item itu realibel adalah dengan melihat hasil uji realibilitas jika setiap variabel > dari 0.6 berarti variabel tersebut realibel. Adapun hasil uji realibilitas dengan menggunakan program SPSS dapat dilihat pada Tabel 12.

Tabel 12 Hasil Uji Realibilitas

\begin{tabular}{lcc}
\hline \multicolumn{1}{c}{ Variabel } & Cronbach's Alpha & Keterangan \\
\hline Isi (X1) & 0.838 & Reliabel \\
Akurasi (X2) & 0.813 & Reliabel \\
Bentuk (X3) & 0.834 & Reliabel \\
Kemudahan (X4) & 0.766 & Reliabel \\
Ketepatan waktu (X5) & 0.817 & Reliabel \\
Kepuasan (Y) & 0.789 & Reliabel \\
\hline
\end{tabular}




\subsubsection{Hasil Uji R}

Uji R digunakan untuk melihat seberapa besar pengaruh variabel X Terhadap Y. Adapun hasil uji $\mathrm{R}$ dengan menggunakan program SPSS dapat dilihat pada tabel 13.

Tabel 13 Hasil Uji R

\begin{tabular}{lcccc}
\hline \multicolumn{4}{c}{ Model Summary } \\
\hline Model & $\mathbf{R}$ & R Square & $\begin{array}{c}\text { Adjusted R } \\
\text { Square }\end{array}$ & $\begin{array}{c}\text { Std. Error of the } \\
\text { Estimate }\end{array}$ \\
\hline 1 & $.850^{\mathrm{a}}$ & .723 & .708 & 2.07395 \\
\hline a. Predictors: & (Constant), Timellines $(X 5)$, Ease of use $(X 4)$, Content $(X 1)$, \\
Format $(X 3)$, Accuracy $(X 2)$ &
\end{tabular}

\subsubsection{Hasil Uji T}

Uji $\mathrm{T}$ menunjukan seberapa besar jauh pengaruh satu variabel independen secara parsial dalam menerangkan variasi variabel dependent. Hasil uji T dapat dilihat pada Tabel 14.

Tabel 14 Hasil Uji T

\begin{tabular}{lcl}
\hline \multicolumn{1}{c}{ Variabel } & Nilai sign.(5\%) & \multicolumn{1}{c}{ Keterangan } \\
\hline Isi (X1) & 0.349 & Tidak signifikan \\
Akurasi (X2) & 0.006 & Signifikan \\
Bentuk (X3) & 0.121 & Tidak signifikan \\
Kemudahan (X4) & 0.057 & Tidak Signifikan \\
Ketepatan waktu (X5) & 0.000 & Signifikan \\
\hline
\end{tabular}

Berdasakan data pada Tabel 14, diketahui 2 variabel $X$ yang tidak berpengaruh terhadap variabel $\mathrm{Y}$, dan terdapat 3 variabel yang dinyatakan berpengaruh terhadap variabel $\mathrm{Y}$ yang dapat dijelaskan sebagai berikut:

a. Hasil uji t variabel Content (X1): nilai signifikansi dari variabel content (X1) sebesar 0.349 lebih besar dari nilai alpha 0.05 dan nilai t hitung sebesar 0.940 lebih kecil dari t tabel 1,664 artinya dapat disimpulkan bahwa variabel content (X1) tidak berpengaruh terhadap variabel Y.

b. Hasil uji t variabel Accuracy (X2): nilai signifikansi dari variabel Accuracy (X2) sebesar 0.006 lebih kecil dari nilai alpha 0.05 dan nilai t hitung sebesar 2.838 lebih besar dari t tabel 1,664 artinya dapat disimpulkan bahwa variabel Accuracy (X2) berpengaruh terhadap variabel Y.

c. Hasil uji t variabel Format (X3): nilai signifikansi dari variabel Format (X3) sebesar 0.121 lebih besar dari nilai alpha 0.05 dan nilai t hitung sebesar 1.566 lebih kecil dari t tabel 1,664 artinya dapat disimpulkan bahwa variabel Format (X3) tidak berpengaruh terhadap variabel Y.

d. Hasil uji t variabel Ease Of Use (X4): nilai signifikansi dari variabel Ease Of Use (X4) sebesar 0.057 lebih kecil dari nilai alpha 0.05 dan nilai t hitung sebesar 1.930 lebih besar dari t tabel 1,664 artinya dapat disimpulkan bahwa variabel Ease Of Use (X4) berpengaruh terhadap variabel Y.

e. Hasil uji variabel Timeliness (X5): nilai signifikansi dari variabel Timeliness(X5) sebesar 0.00 lebih kecil dari nilai alpha 0.05 dan nilai t hitung sebesar 4.794 lebih besar dari t tabel 1,664 artinya dapat disimpulkan bahwa variabel Timeliness (X5) berpengaruh terhadap variabel Y

\subsubsection{Hasil Uji F}

Uji $F$ digunakan untuk mengetahui pengaruh secara keseluruhan antara variabel independen (X) terhadap variabel dependen (Y). Jika nilai sig $<0,05$, atau $\mathrm{F}$ hitung lebih besar dari $\mathrm{F}$ tabel maka terdapat pengaruh secara simultan terhadap variabel $\mathrm{Y}$, dan jika nilai sig $>0,05$, atau $\mathrm{F}$ hitung lebih kecil dari $\mathrm{F}$ tabel maka tidak terdapat pengaruh secara simultan terhadap Y. Hasil uji $\mathrm{F}$ dengan menggunakan program SPSS dapat dilihat pada Tabel 15.

\section{Tabel 15 Hasil Uji F}




\begin{tabular}{|c|c|c|c|c|c|c|}
\hline \multicolumn{7}{|c|}{ ANOVA $^{a}$} \\
\hline & Model & Sum of Squares & df & Mean Square & $\mathbf{F}$ & Sig. \\
\hline 1 & $\begin{array}{l}\text { Regression } \\
\text { Residual } \\
\text { Total }\end{array}$ & $\begin{array}{r}1054.640 \\
404.320 \\
1458.960\end{array}$ & $\begin{array}{r}5 \\
94 \\
99\end{array}$ & $\begin{array}{r}210.928 \\
4.301\end{array}$ & 49.039 & $.000^{\mathrm{b}}$ \\
\hline & $\begin{array}{l}\text { ependent Var } \\
\text { edictors: }(C c \\
\text { racy }(X 2)\end{array}$ & $\begin{array}{l}\text { SUMY } \\
\text { int), Timellines (X5 }\end{array}$ & & use (X4), Cont & X1), $F c$ & $t(X 3)$, \\
\hline
\end{tabular}

Berdasarkan Tabel 15 diketahui nilai signifikasi dari pengaruh variabel X secara simultan terhadap $\mathrm{Y}$ adalah sebesar 0,000 lebih kecil dari nilai alpha 0,05 dan F hitung 49.039 lebih besar dari F tabel 2,31 artinya dapat disimpulkan terdapat pengaruh variabel $\mathrm{X}$ secara simultan terhadap variabel.

\section{KESIMPULAN}

Berdasarkan dari hasil uji $\mathrm{R}^{2}$ dari Tabel 4 diketahui nilai koepesiensi determinasi $\left(\mathrm{R}^{2}\right)$ sebesar 0.850 artinya variabel $\mathrm{x}$ yang terdiri dari Content, accuracy, format, ease of use, dan timeliness secara simultan memberikan pengaruh terhadap variabel Y yaitu User Satisfaction sebesar 0.708 atau $70.8 \%$. Artinya Dari 100 responden menghasilkan 70 responden merasa puas dengan Aplikasi UBD mobile mahasiswa. Berdasarkan hasil uji T pada Tabel 5 diketahui terdapat 2 variabel yang tidak berpengaruh yaitu pada variabel Format dan Content dan terdapat 3 variabel yang berpengaruh terhadap variabel $Y$. Berdasarkan dari hasil uji $\mathrm{F}$ pada Tabel 6, terdapat pengaruh variabel $\mathrm{X}$ secara simultan terhadap variabel.

Pada variabel Content, Format dan Ease Of Use diketahui para pengguna kurang puas terhadap content, Format dan Ease of Use yang dihasilkan oleh Aplikasi UBD mobile mahasiswa untuk itu perlu ditingkatkan lagi kualitas dan kelengkapan yang ada pada sisi Content, Format dan ease of use agar lebih bermanfaat dan berguna bagi penggunanya.

\section{REFERENSI}

[1] W. A. Kusuma, "Sistem Informasi Geografis Pemetaan Lokasi Bird Contest Kota Malang Berbasis Android," SISTEMASI, vol. 7, no. 3, pp. 212-219, 2018.

[2] L. Rusdiana and H. Setiawan, "Perancangan Aplikasi Monitoring Kesehatan Ibu Hamil Berbasis Mobile Android," SISTEMASI, vol. 7, no. 3, pp. 197-203, 2018.

[3] M. Irsan, "Rancang Bangun Aplikasi Mobile Notifikasi Berbasis Android Untuk Mendukung Kinerja Di Instansi Pemerintahan," J. Sist. dan Teknol. Inf., vol. 3, no. 1, pp. 115-120, 2015.

[4] R. N. F. Kosidin, "Pemodelan Aplikasi Mobile Reminder Berbasis Android," in Seminar Nasional Teknologi informasi dan Komunikasi, 2016.

[5] K. R. Hadi, H. M. Az-zahra, and L. Fanani, "Analisis Dan Perbaikan Usability Aplikasi Mobile KAI Access Dengan Metode Usability Testing Dan Use Questionnaire," J. Pengemb. Teknol. Inf. Dan Ilmu Komput., vol. 2, no. 9, pp. 2742-2750, 2018.

[6] A. Fitriansyah and I. Harris, "Pengukuran Kepuasan Pengguna Situs Web Dengan Metode End User Computing Satisfaction (EUCS)," Query J. Inf. Syst., vol. 2, no. 1, 2018.

[7] N. L. A. K. Y. Sarja, "Pengukuran Kepuasan Pengguna Sistem Informasi Dosen Menggunakan Metode Servqual," J. Sist. dan Inform., vol. 12, no. 2, pp. 19-25, 2018.

[8] R. A. Djunanto and F. S. Papilaya, "Analisis Kepuasan Penerimaan Pengguna Akhir Sistem Branch Delivery System (Bds) Pada Layanan Teller Cash Recycler (TCR) Menggunakan End User Computing Satisfaction (EUCS) Dan Iso/Iec 12207: 2008 Pada Perusahaan Bank Di Indonesia," J. Sist. Inf. Indones., vol. 3, no. 1, 2018.

[9] I. G. N. A. Suaryana, E. Damayanthi, and L. Merkusiwati, "Kualitas Dan Kepuasan Pengguna Terhadap Sistem Informasi Akademik Berbasis Web,” J. Ilm. Akunt. dan Bisnis, pp. 84-90, 2016.

[10] F. Maryana, R. Ridhawati, and T. A. Sayekti, "Pengaruh Kualitas Sistem dan Kualitas Informasi terhadap Kepuasan Pengguna Aplikasi Pelayanan Pelanggan Terpusat (AP2T) PT PLN (Persero)

Muhammad Aja Sugandi, R.M. Nasrul Halim, Analisis End-User Computing Satisfaction (EUCS) Pada Aplikas Mobile Universitas Bina Darma 
Wilayah Kalimantan Tengah dan Kalimantan Selatan Area Barabai,” Din. Ekon. Ekon. dan Bisnis, vol. 11, no. 2, pp. 213-229, 2018.

[11] N. Dalimunthe and C. Ismiati, "Analisis Tingkat Kepuasan Pengguna Online Public Access Catalog (OPAC) Dengan Metode EUCS (Studi Kasus: Perpustakaan UIN SUSKA Riau)," J. Ilm. Rekayasa dan Manaj. Sist. Inf., vol. 2, no. 1, pp. 71-75, 2016.

[12] N. L. A. K. Y. Sarja, "Pengukuran Kepuasan Pengguna Sistem Informasi Dosen Menggunakan Metode EUCS," E-Proceedings KNS\&I STIKOM Bali, pp. 836-840, 2017.

[13] R. D. Kristy and W. A. Kusuma, "Analisis Tingkat Kepuasan Dan Tingkat Kepentingan Penerapan Sistem Informasi Universitas Muhammadiyah Malang,” Tek. Eng. Sains J., vol. 2, no. 1, pp. 17-24, 2018.

[14] D. Lusianti, "Pengukuran Kepuasan Peserta JKN Melalui Pendekatan Importance-Performance Analysis," J. Sains Pemasar. Indones. (Indonesian J. Mark. Sci., vol. 16, no. 1, pp. 17-25, 2017.

[15] Sugiyono, Metode Penelitian Kuantitatif Kualitatif dan R\&D. Bandung: Alfabeta, 2015. 